\title{
An Investigation of Historical Geography
}

\author{
Leila Jalali ${ }^{1}$, Farshad Sameni Keivani ${ }^{2}$ \\ ${ }^{1}$ School of Human Science, Department of History, Ataturk University, Erzurum, Turkey \\ ${ }^{2}$ Department of Accounting, Roudsar and Amlash Branch, Islamic Azad University, Roudsar, Iran
}

\begin{abstract}
The historical geography is a part of the human geography to relate with the geographies of the past time and with the impact of the past in shaping the geographies of the other times.

This study investigates concepts of geography, history, historical geography and so on. Geography is very important to history because it shapes the next time of a culture or civilization. Geography is important because it is a main factor in why people choose to live where they do, in how much the people come into contact with others outside their region how battles are fought. Geography can affect all aspects of the people who live in each geographical region. The survey investigates approaches to the teaching of geography, resources of geographic and historical, geographical distributions, spatial histories, location histories and geographical history.
\end{abstract}

Key words: geography, geographical distributions, history and historical geography

\section{Introduction}

History and Geography and are two ways of viewing of the world but they are much closer together that neither one can afford to ignore or even neglect the other. In addition,_every of them offer not just one landscape upon the world but multiple landscapes upon the characters of peoples, places and periods. It is sometimes ratiocinated that historians focus upon people in past periods and historical geographers upon places in past periods. But contrasting geography and history as being concerned respectively with people and with places is a distorted representation of their concerns. The basic difference between them is better explained in terms of history's focus upon periods and geography's focus upon places, fully recognizing that both periods and places were peopled and were constructed and experienced by people.

As the topics of interest to historians have changed, as well as have their view towards geography and to the relations of history and geography. From a restricted attitude of geography either as the physical step upon which the drama of history is enacted or as the framework of political boundaries and physical frontiers within which history is to some extent contained, historians have improved so much broader landscape upon geography which embraces concepts of environment, of space and of place.

Historical geographers explain stories about how places have been created in the past period by people in their own image, while historians explain different stories about how periods have been created in the past by people in their own image.

Geographers and historians have great expansion the range of topics they study. They accept not only almost every possible aspect of human activity but also many features of the natural world: for example, not only canals and criminality but also cotton and climate, not only mining and music but also marshlands and malaria, not only factories and fears and but also forests and furs.

In addition, histories and geographies accept both the actions and the view of individuals and groups, and they do so taking into account the shaping and experiencing of geographies and histories by people who distinct, for example, in terms of their age, class, gender, education or wealth. Moreover, geographies and histories are drawing upon a widening spectrum of cultural, social and literary theories and so on are accepting increasingly diverse landscapes upon historical geographies.

\section{Historical geography}

Historical geography is the study of the people, fictional, theoretical, physical and real geographies of the past time. Historical geography reviews a wide variety of topics. A Joint theme is the reviewing of the geographies of the past time and how a place or region changes during the time. SO many historical geographers review geographical patterns during the time, including how people have interacted with their environment, and created the cultural perspective.

Historical geography looking for to determine how cultural features of various societies across the planet evolved, by understanding their interaction with their local surroundings and environment.

In those early days, Historical geography was difficult to explain as a topic. A textbook from the 1950s cites a prior definition as an unsound attempt by geographers to state history. Its author, J. B. Mitchell, came down 
firmly on the side of geography: 'the historical geographer is a geographer first last and all the time By 1975 the first number of the Journal of historical geography had more extensive the discipline to a broader church: the writings of scholars of any disciplinary provenance who have something to say about matters of geographical interest relating to past time.

Geographic is the studying of a place or area at a specific time in the past time, or the studying of geographic change in a place or area over a period of time. The writings of Herodotus in the 5th century BC, particularly his discussion of how the Nile River delta formed probably provides the earliest example of what would be called historical geography nowadays. When Philipp Cluver, considered the founder of historical geography, published a historical geography of Germany, combining knowledge of the classics with knowledge of the land Historical geography, as the study of past geographies, remained a relatively undeveloped field of study until the 17th century. In the 19th century the importance of geography as the basis for understanding history was teach in many universities, particularly in Great Britain. Geography as the base for understanding history changed to the geographic influence upon historical events in the early 20th century. The work of Ellen Churchill sample used this environmental deterministic interpretation of history. From the 1930s, historical geography gained prominence through the valuable studies in sequent occupancy, the study of the people occupation of a specific region over intervals of historic time-initiated by Derwent S. Whittlesey and Carl O. Sauer.

\section{Approaches to the teaching of geography}

Approaches to the teaching of geography can be expressed as follows:

Regional Approach: Here students systematically study world culture regions and interactions among regions. For example, a unit on West Africa might include an examination of the factors that influenced forced migration between the region and North America in the 18th and early 19th Centuries, a unit on Japan might focus, in part, on how the cultural perspective was affected over time by the threat of earthquakes, and a unit on Western Europe might, among other considerations, focus on political revolutions, their origins, diffusion, and impact on other world regions.

Chronological Approach: Here students study geographic and historical subjects during particular regions. For example, a unit focusing on the Industrial Revolution in Europe might also examine related developments in trade, urbanization, migration, and the spread of disease that occurred during that same region.

Thematic Approach: Here students study particular geographic and historical subjects or problems for particular time periods. For example, one unit of study may be concerned with urbanization in different societies over time, a second with the development of nation-states, and a third with conflict and cooperation in modern times, as indicated by economic agreements and political treaties.

\section{Resources of geographic and historical}

To obtain geographic and historical information related to these questions from a variety of primary and secondary sources, such as books, visual representations, atlases, artifacts, archival collections, and other written documents, statistical source material, remote sensing, historic sites, fieldwork and interviews, Global Positioning Systems and Geographic Information Systems, and electronic sites.

Produce maps, timelines, and other graphic representations to organize and display the geographic and historical information obtained.

Interpreted maps, schedule, and other graphic representations to solve geographic and historical problems and to analyze world events and suggest applied solutions to world problems.

Reach conclusions about the geographic and historical questions posed and give verbal, written, graphic, and cartographic expression to results.

\section{The historical geography concepts for using of Geography and History of the World}

The historical geography implications used to investigate global themes in History and Geography of the World are explained below.

Change Over Time: Modifications in people and physical Surroundings resulting from the workings of historical and geographic procedures.

Cultural Landscape: The forms and artifacts sequentially placed on the natural perspective by the activities of various human occupants. By this progressive imprinting of the human presence, the physical perspective is amended into the cultural perspective, forming an interacting unity between them.

Diffusion: The spatial spreading or dissemination of a culture element or some other phenomenon.

Human Environment Interactions: The ways that people depend on, adapt to, are affected by, and change the natural environment. 
Human Livelihoods: People obtain the necessities and the comforts of life through participation in three sectors of activity: Primary sector (agriculture, mining, and forestry), Secondary sector (industry), and Tertiary (services).

National Character: Overtime, countries and nations take on representative cultural features that define them locally, regionally, or nationally and collectively distinguish them from others.

Origin: The point or place from which something arises, comes, begins, or develops; the starting point or place. Physical Systems: The physical processes that shape the patterns of the Earth's surface and the characteristics and spatial patterns of ecosystems on Earth's surface.

Sense of Place: Places are parts of earth's space, large or small, that have been endowed with meaning by people. A sense of place takes two forms: the distinctive character of a place that results from the physical characteristics of the place or the place's association with significant events, and the attachments that people develop for places through experience, memory, and intention.

Spatial Distribution: The arrangement of physical and human elements on the Earth's surface.

Spatial Interaction: The movement of people, goods, information and money between and among regions, countries and places.

Spatial Organization: The way in which physical and human elements on the Earth's surface are structured.

Spatial Variation: How one place is different from another, deviation in form, condition, appearance, extent?

\section{Geographical distributions}

The problems of making and interpreting maps of historical data are intrinsically serious but they are often neglected, sometimes ignored. The geographical interpretation of historical sources is a skill which can provide a distinctive insight into some aspect of the past (Baker et al. 1970). But such interpretation has to be conducted with circumspection. Very often, the historical sources themselves are not explicitly geographical, having been compiled for non-geographical purposes. It thus becomes necessary to build from and into such source materials the required location or spatial dimension. In order to do so, a historical geographer has to contextualize the source material being employed: this involves understanding the purposes for which, and the manner in which, the material was compiled. It is not unusual for the survival of historical data to be incomplete, or indeed for the original collection of the data to have employed non-standard measures and also not to have covered the whole time period, geographical area or range of topics under examination. Apparently negative areas in a mapped distribution pattern might well be explicable in terms of the manner in which the source was originally compiled, not necessarily in terms of the absence of the phenomenon being studied. Again, a further complication is that the areal units to which a historical source refers might long since have disappeared and their location and size - or some surrogates for them - have to be reconstructed before the data can be mapped.

\section{Spatial histories, location histories and geographical history}

Study of the influence of geographical conditions upon the course of history - what was called 'the geography behind history' - has a long and in many ways distinguished pedigree. While studies couched in that framework had many merits, they also had their faults, notably their tendency to equate 'geographical influences' with 'physical geographical influences' and their associated tendency to lean towards environmental determinism as a form of geographical explanation. But geographical perspectives upon history were considerably broadened and enriched under Fernand Braudel's influence to include the concepts of space and location (Lepetit 1986a). Increasingly, historians have been adopting a wider range of geographical concepts and they have been doing so when, paradoxically, some geographers have been arguing for a narrowing of the conception of historical geography, limiting it to what they call 'geographical history'. I will consider each of these stances in turn.

In the $1950 \mathrm{~s}$, Braudel was pleading that history and the social sciences should make room for an increasingly geographical conception of humanity, a conception which would embrace not only the influences of the physical environment but also those of space and location (Braudel 1958). He was doing so on the eve of a great surge of interest by geographers in the 1960s and 1970s in spatial and location analysis. That wave, powered largely by the modernising forces of quantification and by the seekers of order in (and scientific respectability for) geography, was to engulf much of the field of human geography in those decades, leaving only islands of humanistic geography from which alarm calls could be sounded and preparations made for the recovery that would be needed after that flood had receded (Harris 1971, 1978a). Damage was done to human geography by the excesses of the so-called 'quantitative revolution' and by unjustifiable claims to geography's 'ownership' of space as a concept, but I am very willing none the less to concede that both the project and the methods of geography as spatial analysis have enriched the practice of a historical geography focused on the processes of the social organization of space through time, as Jakle (1971) had suggested they might. 
Not only geography but also history have been - and might still further be -a beneficiary of even closer attention to spatial and locational concepts. Let me illustrate this point at both continental and global scales. As a historian, Edward Cook (1980) has undertaken a critical review of the kinds of insights which historians can gain from geography and emphasised the ways in which they might profit from 'a heightened sense of the spatial dimensions of their studies'. His review was specifically of 'spatial approaches to early American history'. For Cook, 'a first step in the application of geographical thought to history is the simple but unfamiliar one of approaching problems with spatial influences as clearly in mind as those of time and cultural institutions' and he noted that 'a key part of the geographer's procedure involves asking each source how its data would look imposed on a map of the area in question'. Cook cites and praises work on colonial America by geographers like Carville Earle, Roy Merrens, Cole Harris and James Lemon, noting the emphasis which they all placed on real differences and on spatial relations in their understandings of the periods and places they were studying. More specifically, Cook considered critically the extent to which early American history had been illuminated by the application of locational theory in general and of central place theory in particular, referring to work by geographers such as James Vance Jr, Michael Conzen, Robert Mitchell and Allan Pred. For Cook, 'implicit in the view of geography as a strategy for thinking in spatial terms is its usefulness in a wide range of historical situations' (Cook 1980: 20,23). He could have added 'and at a wide range of geographical scales', because spatial and locational principles may also be insightful in different geographical contexts.

They can, for example, be applied at the global scale, as they have been so effectively by a French historian, Chaunu (1974), in his broad-brush portrayal of the history and geography of the world. Chaunu presented his work in three parts. The first part, La dur'ee, examined the history of history, the relations between history and the social sciences, the concept of discontinuity in history, and the succession of civilizations; the second part, L'espace, considered what Chaunu termed 'the rules of space', examined the global distribution of food production and traced the transformation of essentially discrete 'worlds' into an integrated global economy; and the third part, L'homme, moved towards a historical demography of the world and of its different civilizations. This ambitious, stimulating work drew upon a range of geographical concepts, especially those of distribution, difference and distance, and of spatial relations and interactions. It made frequent and effective use of maps (for example, a world map of civilisations, cultures and primitive people's $c$. 1500 ) as well as of graphs (for example, of literacy levels in Scotland, England and France, 1600-1900). While Chaunu made no distinction between 'geohistory' and 'historical geography', using the terms interchangeably, it is noticeable that he drew his inspiration explicitly from the geohistory of Braudel, with only passing references to the work of geographers (and then to members of the founding generation of French geographers, PaulVidal de la Blache and Albert Demangeon, rather than to any of his own contemporaries).

Similarly broad and explicitly geographical approaches to world history are exhibited in Grataloup's (1996) Lieux d'histoire: essai de g'eohistoire syst'ematique and in Trochet's (1998) La g'eographie historique de la France, which again indicates how the terms 'geohistory' and 'historical geography' are being used interchangeably by some French historical geographers as well as by some historians. Grataloup provides an examination of the roles of space, location and distance in the histories of societies at global, continental, national and city scales from the Neolithic to the Industrial Revolution. He even offers some simplified, graphical, geohistorical models of specific societies. Trochet addresses the organisation of space as territories in traditional societies. He deals first with the use of space as territory by various social groups, such as families and local communities, and tribes and peoples, and then he considers the territorial and spatial aspects of citystates, empires and nation-states. Chaunu's work on what he terms 'the geohistory of wheat' and of other crops and Grataloup's work on 'the geohistory of sugared-tea' both have considerable affinity with the kind of work associated in the English-speaking world with the Berkeley school of cultural geography. But, inspired by Braudel, Chaunu and Grataloup have dared to produce global-scale historical geographies of the world, whereas the work of the Berkeley school has - as it seems to me - disappointingly not been much greater than the sum of its parts. Within the English-speaking world, the most provocative ideas about the historical processes of economic globalisation have been provided by Immanuel Wallerstein's world-system theory (Wallerstein 1974, 1980). Again, like Chaunu's geohistorical work, Wallerstein's geographical perspective upon the history of capitalism was inspired by Braudel.World-system theory is a spatial and temporal model which identifies three components, those of core, semi-periphery and periphery, and which envisages individual countries moving in and out of these three categories in a non-evolutionary manner. Wallerstein saw the capitalist world-system first emerging in Europe during the fifteenth and sixteenth centuries. Itwas a system based upon unequal exchange, with core areas exchanging high-value manufactured goods for low-value primary products, rawmaterials and food from peripheral areas. The initial European core embraced nations competing amongst each other for global economic hegemony, but itwas subsequently to pass to European-settled colonies, notably the USA, and to countries like Japan which adopted European economic and technological ideas and systems. While some countries formed the core of the system and others the periphery, still others could move between the two sets and were accordingly themselves part of the semi-periphery. It is not my purpose here to appraise world-system 
theory. I want merely to stress the extent to which it draws on spatial - and so, in that limited sense, geographical - concepts.

Some geographers have in turn picked up world-system theory and incorporated it into their own perspectives upon the historical and geographical development of capitalism (Taylor 1985; Nitz 1987; Kearns 1988). Some significant 'big-picture' perspectives upon the development of the modern, capitalist world during the past five hundred or so years are nowbeing provided by geographers. For example, Peter.

\section{References}

[1]. Alan r. H. Baker, (2005), geography and history bridging the divide, emmanuel college, Cambridge

[2]. "Approaches to History and Geography," Middle States Council for the Social Studies 2001 Yearbook. Lawrenceville, NJ: Middle States Council for the Social Studies. 2001.

[3]. Alan Pred, Urban Growth and the Circulation of Information: the United States' System of Cities, 1790-1840 (Cambridge, Mass., 1973); Robert A. Dodgshon, Society in Time and Space: a Geographical

[4]. Bradley Commission on History in Schools, Building a History Curriculum: Guidelines for Teaching History in Schools, National Council for History Education ,1988

[5]. Donald Meinig, The Shaping of America: A Geographical Perspective on 500 Years of American History, [New Haven: Yale University Press, 1987], xv.

[6]. Essential History Content K-12," Middle Sates Council for the Social Studies 2001 Yearbook. Lawrenceville, NJ: Middle States Council for the Social Studies. 2001.

[7]. Bruce M. S. Campbell and Ken Bartley, England on the Eve of the Black Death: an Atlas of Lay Lordship, Land and Wealth, 130049 (Manchester, 2006); Mark Overton, Agricultural Revolution in England: theGeography for Life: National Geography Standards 1994. Washington D. C.: National Geographic Research and Exploration, 1994.

[8]. National Standards for History, Los Angeles: National Center for History in the Schools, 1996

[9]. Geography for Life: National Geography Standards 1994. Washington D. C.: National Geographic Research and Exploration, 1994, pages 46-56. National Standards for History, Los Angeles: National Center for History in the Schools, 1996, 14-24

[10]. Geography for Life: National Geography Standards 1994. Washington D. C.: National Geographic Research and Exploration, 1994.

[11]. Robin Butlin, Historical Geography: Through the Gates of Space and Time (London, 1993), pp. 1-23.

[12]. H. C. Darby, The Relations of History and Geography: Studies in England, France and the United States (Exeter, 2002).

[13]. Period and place: research methods in historical geography. Edited by alan r. h. baker and m. billinge

[14]. The historical geography of Scotland since 1707: geographical aspects of modernisation. david turnock

[15]. Historical understanding in geography: an idealist approach. leonard guelke

[16]. English industrial cities of the nineteenth century: a social geography. r. j. dennis

[17]. Explorations in historical geography: interpretative essays. Edited by alan r. h. baker and derek gregory

[18]. The tithe surveys of England and Wales. r. j. p. kain and h. c. prince

[19]. Human territoriality: its theory and history. robert david sack

[20]. The West Indies: patterns of development, culture and environmental change since 1492. david watts

[21]. The iconography of landscape: essays in the symbolic representation, design and use of past environments. Edited by denis cosgrove and stephen daniels

[22]. Sameni Keivani. Farshad et al, 2013, “The Estimation of the Potential Capacity of Zakah -A Case Study of Iran”, Journal of Basic and Applied Scientific Research, text road, ISSN 2090-4304

[23]. Sameni Keivani. Farshad et al, 2013, "The Estimation of the Underdevelopment Degree of Different Regions- A Case Study of the Cities of Guilan Province in Iran" World Applied Sciences Journal, 22 (10): 1395-1400, 2013, ISSN 1818-4952

[24]. Sameni Keivani. Farshad et al, "The Historical Lack of Capital Accumulation in Iran's Agricultural Part", 11(5) IOSR Journals of Business and Management (IOSR-JBM) e-ISSN: 2278-487X, p-ISSN: 2319-7668. Volume 10, Issue 4 (May. - Jun. 2013), PP 88-90

[25]. Urban historical geography: recent progress in Britain and Germany. Edited by dietrich denecke and gareth shaw 